\title{
Soil and Water Loss Rates in Oxisols Under No-tillage System in Western Paraná, Brazil
}

\author{
Luana Salete Celante ${ }^{1}$, Deonir Secco ${ }^{1}$, Aracéli Ciotti de Marins ${ }^{2}$, Daniela Trentin Nava ${ }^{2}$, Flávio Gurgacz ${ }^{1}$, \\ Luiz Antônio Zanão Júnior ${ }^{3}$, Luciene Kazue Tokura ${ }^{1}$, Samuel Nelson Melegari de Souza ${ }^{1}$ \\ $\&$ Reginaldo Ferreira Santos ${ }^{1}$ \\ ${ }^{1}$ Pos-Graduation Program, State University of West Paraná, Cascavel, Paraná, Brazil \\ ${ }^{2}$ Department of Mathematics, Federal Technological University of Paraná, Toledo, Paraná, Brazil \\ ${ }^{3}$ Agronomic Institute of Paraná, Santa Tereza do Oeste, Paraná, Brazil \\ Correspondence: Luciene Kazue Tokura, Pos-Graduation Program, State University of West Paraná, Rua \\ Universitária, 2069, Jardim Universitário, CEP: 85819-110, Cascavel, Paraná, Brazil. Tel: 55-(45)-3220-3151. \\ E-mail: lucienetokura@gmail.com
}

Received: June 9, $2018 \quad$ Accepted: July 14, $2018 \quad$ Online Published: September 15, 2018

doi:10.5539/jas.v10n10p132 URL: https://doi.org/10.5539/jas.v10n10p132

\begin{abstract}
The objective of work was to quantify soil and water loss rates as a function of slope variation, correlating these rates with soybean yield. In addition to developing multiple linear regression models that associate water and soil loss rates in function of their physical attributes. The experiment was conducted in an Oxisols under a no-tillage system. The experiment was carried out in Cascavel, PR, Brazil. Four slopes (3.5\%; 8.2\%; $11.4 \%$ and $13.5 \%)$ were considered as treatments. The water and soil loss rates were monitored in the rainfall occurring during the crop development cycle. The water drained in each plot was collected in gutters made of polyvinyl chloride and stored in containers for the quantification of soil and water losses. The stepwise backward method was used to identify the variables that had a significant influence on water and soil losses. The unevenness of the terrain did not influence the soil and water loss rates. The maximum soil and water losses during the soybean cycle were, respectively, $0.01962 \mathrm{Mg} \mathrm{ha}^{-1}$ and $4.07 \mathrm{~m}^{3} \mathrm{ha}^{-1}$. The maximum soil and water losses occurred when the precipitation volume was up to $82 \mathrm{~mm}$. Soil and water losses showed a higher correlation with macroporosity and bulk density. Soybean grain yield showed a higher linear correlation with water, and soil loss and was higher at the slopes of $8.2 \%$ and $13.4 \%$. The low water and soil losses demonstrate the soil capacity, managed under a no-tillage system, to minimize environmental impacts.
\end{abstract}

Keywords: water erosion, mathematical model, physical-hydraulic attributes

\section{Introduction}

The basic principle of SPD is the constant coverage in the soil with plant residues from other crops. In addition to the diversification of crops of multiple species, about crop rotation, succession, intercropping and conservative soil management systems (Tiecher et al., 2014). The same authors still report that only a fraction of the cultivated areas in Brazil follow all the fundamental principles of this conservationist system.

As most farmers do not use adequate soil management or conservation techniques, erosion losses are still high in Brazil. Millions of tons of agricultural soil are lost each year due to erosion (Oliveira et al., 2010). Thus, no-tillage system is an alternative to reduce these losses, because the straw that remains on the soil surface acts as a physical protection against water and soil losses, besides improving the chemical, physical and biological characteristics of the soil (Moline et al., 2011).

Costa et al. (2007) also state that erosive processes have been the subject of continuous concern with the management and use of soil, particularly with reflections on crop productivity and environmental quality. Erosion is seen as an event that contributes the most to soil degradation, with subsequent negative effects on crop productivity and environmental pollution (Santos et al., 2013). According to Bertol, González, and Vázquez (2007), irrespective of the management system used, the cost relating to annual fertilizer losses due to water erosion is relatively high. 
Minella et al. (2007) define erosion as the process in which soil particles are detached from their cohesive matrix and then loaded in the downstream direction by a transport agent. The soil surface flow is the most influential factor for erosion, being determined by soil slope, water infiltration capacity, surface roughness, and soil cover percentage (Carvalho et al., 2012; Fontana et al., 2016).

Attributes such as texture, organic matter content and stability of the aggregates, soil handling, rainfall intensity, etc. may determine soil erodibility (Martins Filho et al., 2001; Cogo, Levien, \& Schwarz, 2003; Amaral et al., 2008; Santos et al., 2013) According to Carlesso et al. (2011), the increase of rainfall intensity causes a reduction in time for the beginning of water surface runoff in the soil, causing increase in losses, regardless of soil surface conditions.

Cogo, Levien, and Schwarz (2003) and Bertol, González and Vázquez (2007) cite the terrain slope as another factor that influences soil and water losses due to water erosion. According to the authors, as the slope increases, it affects the volume and speed of the runoff, thus reducing the infiltration of water into the soil.

Soil physical attributes such as bulk density, macroporosity and microporosity and saturated hydraulic conductivity (ksat) also influence water and soil loss, since an alteration of these attributes directly implies the infiltration of water in the soil (Mesquita \& Moraes, 2004; Sousa, Martins Filho, \& Matias, 2012; Primo et al., 2015).

Because of the soil losses caused by erosive processes, there is an impact on the soil thickness, reducing its retention capacity and redistribution of water in its profile, resulting in higher surface flows and, subsequently, higher rates of soil erosion (Hamza \& Anderson, 2005; Santos, Griebeler, \& Oliveira, 2010).

Losses of soil and water caused by surface runoff may cause major damage to agricultural crops and lead to contamination of watercourses. Thus, studies on water and soil loss can guide decision-making processes on the adoption of conservation practices for erosion control.

Considering the above, this research aimed to quantify soil and water loss rates in an Oxisols under a no-tillage system, relating these rates to soybean grain yield, and to develop models that associate soil and water loss rates as a function of the physical-hydraulic attributes that best correlate with these losses.

\section{Material and Methods}

\subsection{Location and Characterization of the Experimental Area}

The experiment was carried out in a commercial soybean crop in the municipality of Cascavel, PR at latitude $25^{\circ} 03^{\prime} 28.84^{\prime \prime} \mathrm{S}$, longitude $53^{\circ} 26^{\prime} 25.48^{\prime \prime} \mathrm{W}$ and an average altitude of $655 \mathrm{~m}$. The climate of the region is subtropical, according to the Köppen classification (Cfa) (IPARDES, 2012), with annual average rainfall ranging from $1600 \mathrm{~mm}$ to $2000 \mathrm{~mm}$ (Caviglione et al., 2000).

The study was conducted in the 2015/2016 crop, under a no-tillage system (NTS), during the soybean crop cycle on the wheat straw. Following demarcation of the sampling scheme, soil samples were taken for the determination of particle size in the layers of $0-0.1$ ( $4.1 \%$ sand, $37.4 \%$ silt, and $58.5 \%$ clay); $0.1-0.2$ ( $2.8 \%$ sand, $38.3 \%$ silt, and $58.9 \%$ clay), and $0.2-0.3 \mathrm{~m}$ ( $2.2 \%$ sand, $38.5 \%$ silt, and $59.3 \%$ clay).

The soil was classified as a typical Dystroferric Red Latosol with a clayey texture (EMBRAPA, 2013). For chemical characterization of the soil, samples were collected in the 0-0.1 m layer (Table 1).

Table 1. Chemical characterization of the soil

\begin{tabular}{|c|c|c|c|c|c|c|c|c|c|c|}
\hline $\mathrm{PH}$ & $\mathrm{P}$ & $\mathrm{C}$ & $\mathrm{AL}$ & $\mathrm{H}+\mathrm{AL}$ & $\mathrm{CA}$ & $\mathrm{MG}$ & $\mathrm{K}$ & SB & $\mathrm{T}$ & $\mathrm{V}$ \\
\hline & $\mathrm{MG} \mathrm{DM}^{-3}$ & $\mathrm{G} \mathrm{DM}^{-3}$ & ----. & - & ----- & $\mathrm{MOL}_{\mathrm{C}}$ & $I^{-3}---$ & ------ & ---------- & $--\%--$ \\
\hline 4.9 & 23.4 & 21.81 & 0.11 & 6.68 & 8.05 & 2.52 & 0.87 & 11.44 & 18.12 & 63.1 \\
\hline
\end{tabular}

Note. P: Available phosphorus; C: Organic carbon; Al: Exchangeable aluminum; H + Al: Potential acidity; Ca: Available calcium; Mg: Magnesium available; K: Potassium available; SB: Base sum; T: Cation exchange capacity; V: Base Saturation.

\subsection{Field Establishment of Experiment}

Four collection gutters with $3 \times 3 \mathrm{~m}$ in area, delimited with grass edging, were built and buried at a height of up to $0.10 \mathrm{~m}$. In the direction of the greatest terrain slope, the collection gutters were installed to collect the runoff, which flowed into polyvinyl chloride tubes $(0.2 \mathrm{~m}$ diameter $)$ cut in half, where the volume of the runoff was 
stored in 50-liter collecting containers (Figure 1). The gutters were allocated to the soybean crop with pre-established slopes of $3.5 \%, 8.2 \%, 11.4 \%$, and $13.5 \%$.

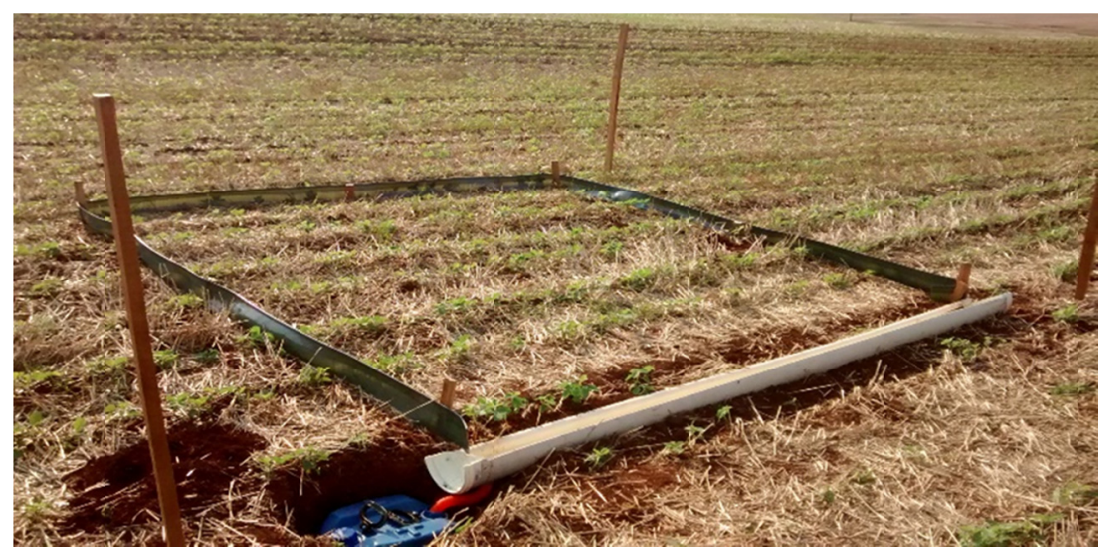

Figure 1. Collection gutters for quantification of water and soil losses

\subsection{Analyzed Variables}

After each precipitation, water and soil loss by surface runoff, stored in the collection vessels of each treatment, were quantified. The volume of water drained after each precipitation was determined directly by graduated test tubes. For the quantification of the mass of soil lost, a representative sample of the volume of the runoff was withdrawn into the collection vessel after homogenization. Subsamples of $50 \mathrm{ml}$ were removed from the samples of the flood volume collected in the field and placed in the oven at a temperature of $105^{\circ} \mathrm{C}$ for evaporation of water. After evaporation, the amount of soil lost by erosion was quantified. Thus, from the mass of soil quantified in $50 \mathrm{ml}$, the total mass of soil lost was extrapolated to each rainfall.

Bulk density (BD), particle density (PD), total porosity (PT), macroporosity (Macro), microporosity (Micro) and saturated hydraulic conductivity (Ksat) were determined according to the methodology recommended by EMBRAPA (2011).

Soybean was sown on October 12, 2015, throughout the experimental area. The harvest was carried out manually on January 28, 2016, in the delimited area of $9 \mathrm{~m}^{2}$ of the gutter. To evaluate the yield of the soybeans, moisture was corrected to $13 \%$. The number of soybean plants was quantified, and their relative yield was determined in the evaluation of grain yield.

The rainfall data of the harvest days during the soybean cycle are presented in Figure 2.

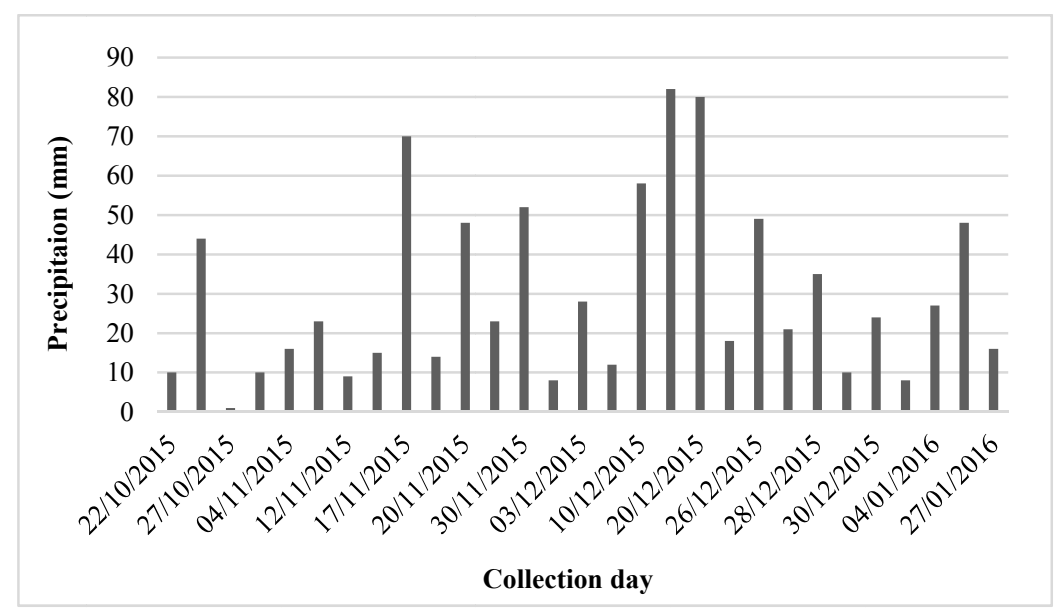

Figure 2. Precipitation data during the soybean development cycle 
According to Figure 2, it is verified that, throughout the development cycle of the soybean crop, no lack of water was evidenced for its full development, given the volume and frequency of rainfall. It was also verified that the maximum precipitated volume was $82 \mathrm{~mm}$. The precipitation during the soybean cycle was $859 \mathrm{~mm}$. This precipitation was higher than that reported by Farias, Neumaier, and Nepomuceno (2015). These authors affirm that, for a good soybean development and productivity, 500 to $700 \mathrm{~mm}$ of precipitation is required during the soybean cycle.

The experimental design was completely randomized. The treatments were the four slopes, and the replications were the 29 precipitations occurred during the soybean cycle.

\subsection{Statistical Analysis of the Data}

For the comparison of soil loss, water and soybean grain yield, Tukey's test was used at a significance level of $5 \%$. For the analysis of the data and generation of the regression models and graphs, the statistical program $\mathrm{R}(\mathrm{R}$ CORE TEAM, 2016) was used. The stepwise backward method was used to evaluate the most significant variables.

\section{Results and Discussions}

\subsection{Physical-hydric Attributes}

The mean values of bulk density, saturated hydraulic conductivity, macroporosity, microporosity and total porosity in the $0-0.1 \mathrm{~m}, 0.1-0.2 \mathrm{~m}$, and $0.2-0.3 \mathrm{~m}$ layers are shown in Table 2 .

Table 2. Values of total porosity (TP), macroporosity (Macro), microporosity (Micro), saturated hydraulic conductivity (Ksat) and bulk density (BD) of the experimental area, in the $0-0.1 \mathrm{~m}, 0.1-0.2 \mathrm{~m}$ and $0.2-0.3 \mathrm{~m}$ layers

\begin{tabular}{lllllll}
\hline Slopes & Layer & TP & Macro & Micro & Ksat & BD \\
\hline 3.5 & -0.1 & 55.20 & 19.47 & 35.73 & 120.4 & 1.28 \\
& $0.1-0.2$ & 57.35 & 22.01 & 35.34 & 3.5 & 1.31 \\
& $0.2-0.3$ & 55.42 & 24.22 & 31.20 & 9.8 & 1.37 \\
\hline 8.2 & Mean & 55.99 & 21.90 & 34.09 & 44.6 & 1.32 \\
& $0-0.1$ & 57.22 & 19.33 & 37.88 & 31.1 & 1.22 \\
& $0.1-0.2$ & 58.23 & 21.18 & 37.05 & 10.8 & 1.28 \\
\hline 11.4 & $0.2-0.3$ & 55.49 & 18.43 & 37.05 & 2.3 & 1.37 \\
& Mean & 56.98 & 19.65 & 37.33 & 14.7 & 1.29 \\
\hline 13.4 & $0-0.1$ & 50.45 & 15.25 & 35.20 & 6.1 & 1.42 \\
& $0.1-0.2$ & 55.94 & 21.80 & 34.14 & 45.2 & 1.35 \\
& $0.2-0.3$ & 58.63 & 20.29 & 38.34 & 5.6 & 1.27 \\
& Mean & 55.01 & 19.11 & 35.89 & 19.0 & 1.34 \\
\hline & $0-0.1$ & 53.39 & 17.11 & 36.28 & 3.3 & 1.33 \\
& $0.1-0.2$ & 55.31 & 21.23 & 34.08 & 44.6 & 1.37 \\
& $0.2-0.3$ & 55.58 & 21.32 & 34.26 & 5.9 & 1.36 \\
\hline Mean & 54.76 & 19.89 & 34.87 & 17.9 & 1.35
\end{tabular}

The mean values of bulk density are within the critical limits for Oxisols (Table 2). According to Reichert, Reinert and Braida (2003) the critical values for clayed soils are from 1.30 to $1.40 \mathrm{Mg} \mathrm{m}^{-3}$. Argenton et al. (2005) reported that $\mathrm{BD}$ values close to $1.30 \mathrm{Mg} \mathrm{m}^{-3}$ for clayey soils limited soil gas exchange, while Klein (2006) found a limiting bulk density of $1.33 \mathrm{Mg} \mathrm{m}^{-3}$, based on the optimal water range, especially for the development of crops in clayey Latossol.

In general, all slopes present values of $\mathrm{BD}$ in the range that requires attention, which, according to Panachuki et al. (2011), may result in a reduction in the rate of water infiltration in the soil, with a subsequent increase in surface runoff rates, as well as interfering with water and soil loss.

As for soil macroporosity, the percentages found are above $10 \%$, considered adequate according to Tormena et al. (2002) and Reichert et al. (2009), as values lower than 10\%, according to Beutler and Centurion (2003), interfere 
in the respiratory demand of the roots, growth and activity of microorganisms, drainage and aeration of the soil, and absorption of water and nutrients. Thus, all treatments present macroporosity above the minimum acceptable range recommended for the good development of the plants.

The Ksat values presented great variability, corroborating the results found by Fontana et al. (2016), in Latosols under soybean cultivation, and Primo et al. (2015), who verified that the Ksat tends to decrease according to the depth due to the densification.

\subsection{Water and Soil Loss}

Soil and water loss presented high variability, making the set of values heterogeneous (CV of $133.98 \%$ for soil loss and $74.36 \%$ for water loss) (Table 3), according to Vanni (1998).

Soil loss varied from 0.029 to $19.62 \mathrm{~kg} \mathrm{ha}^{-1}$, while the average loss in the four soil differences was $1.27 \mathrm{~kg} \mathrm{ha}^{-1}$. Water loss, in turn, varied from 35 to $4074 \mathrm{~L} \mathrm{ha}^{-1}$, while the average loss in the four slopes was $1040 \mathrm{~L} \mathrm{ha}^{-1}$ (Table 3).

In the analysis of variance, it was verified that there was no significant difference at $5 \%$ probability between the slopes for water loss. According to Leite et al. (2009), the water loss results have not presented consistency, with similar water losses between the soil management systems depending on the rain regime, soil type, topography, and management systems. Bertol (1994) also states that water losses may be similar among different soil preparation methods, because the soil presents limited water infiltration capacity. Bertol, Cogo, and Levien (1989), Levien et al. (1990), Schick et al. (2000), Cogo, Levien, and Schwarz (2003) also stated that water losses were little influenced by soil management systems, regardless of soil slope.

Table 3. Descriptive statistics of soil and water losses during the soybean cycle

\begin{tabular}{lll}
\hline Statistic & Soil loss $\left(\mathrm{Mg} \mathrm{ha}^{-1}\right)$ & Water loss $\left(\mathrm{m}^{3} \mathrm{ha}^{-1}\right)$ \\
\hline Min. & $2.9 \times 10^{-5}$ & 0.035 \\
Q1 & $4.1 \times 10^{-4}$ & 438.30 \\
Med. & 0.001267 & 1.040 \\
Q2 & 0.003058 & 1233.00 \\
Q3 & 0.003839 & 2000.00 \\
Max. & 0.01962 & 4.074 \\
S & 0.0040977 & 916.59 \\
CV & 133.98 & 74.36 \\
As. & 2.019 & 0.811 \\
K & 6.9170 & 3.052 \\
\hline
\end{tabular}

Note. Min.: Minimum; Q1: $1^{\text {st }}$ quartile; Med: Mean; Q2: $2^{\text {nd }}$ quartile or median; Max.: Maximum; S: Standard deviation; $\mathrm{S}^{2}$ : Variance; CV: Coefficient of variation; As.: Asymmetry; K: kurtosis.

Water loss values were lower than those observed by Silva and De Maria (2011), and Ramos et al. (2015). Although it is considerably low, water loss can be detrimental to the environment, mainly linked to the area of a river basin, as the flood constitutes the main transport agent for nutrients and sediment to the water sources (Bertol, González, \& Vázquez, 2007).

The variables that influenced water loss the most were bulk density (BD), macroporosity (Macro) and saturated hydraulic conductivity (ksat), according to the Stepwise Method.

Thus, water loss graphs were generated as a function of BD and Macro, BD and ksat, and Macro and ksat.

Figure 3 shows the relationship of water loss involving BD, ksat, and Macro, two by two. 

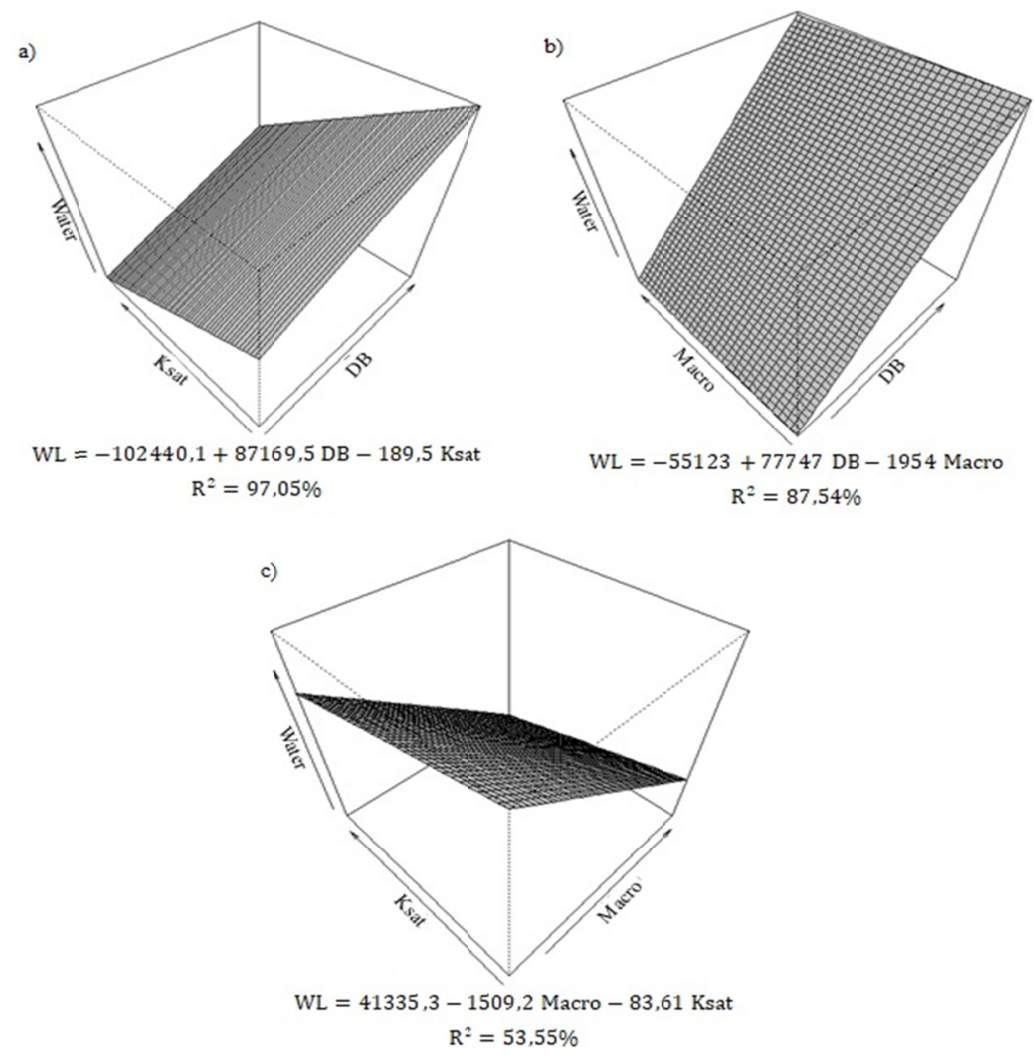

Figure 3. Graphs of the mathematical models for water loss as a function of BD vs. Macro (a), BD vs. ksat (b), and Macro vs. Ksat (c)

Figure 3(a) shows that with the increase in BD and the reduction in Ksat, there is an increase in water loss. Figure 3(b), in turn, shows that, regardless of the Macro, the increase in BD caused greater water loss. In Figure 3(c), it is verified that, with the reduction of Macro and ksat, there is an increase in water loss. Thus, higher BD values generate lower Macro and ksat values and, subsequently, higher water loss rates. These results corroborate the results of Klein (2006), and Minella et al. (2007).

Thus, according to the results obtained, the mathematical model that presented the highest coefficient of determination in the quantification of water loss was comprised the association with $\mathrm{BD}$ and Ksat (Equation 1).

$$
\text { Water Loss }=-102440.1+87169.5 \mathrm{BD}-189.5 \mathrm{Ksat} \quad\left(\mathrm{R}^{2}=97.05 \%\right)
$$

There was no significant difference in soil loss in the different slopes. The results show higher total soil loss in the slope of $13.4 \%$, but still lower than that observed by Silva et al. (2009), while Marques, Weill, and Silva (2010) recorded losses of $206 \mathrm{~kg} \mathrm{ha}^{-1}$. Cândido et al. (2014), in turn, found smaller values in planting with crop residue differences.

The data rainfall was collected, only during the soybean cycle. Considering that the mean daily soil loss in rainy days was $0.001267 \mathrm{Mg} \mathrm{ha}^{-1}$, these values are lower than those observed by Michellon, Reydon, and Chicati (2014), who find average soil losses in a no-tillage system in the state of Paraná of $9.7 \mathrm{mg} \mathrm{ha}^{-1}$ year $^{-1}$.

Bertol et al. (2001) found higher soil loss values $\left(1.2 \mathrm{Mg} \mathrm{ha}^{-1}\right)$ in a no-tillage system, but still lower than in other tillage systems.

Other researchers have obtained higher values in comparison to this study. One can cite Lanzanova et al. (2013), which found soil losses varying from 0.63 to $1.32 \mathrm{Mg} \mathrm{ha}^{-1}$ year $^{-1}$, with the no-tillage system showing the lowest soil loss rates, corroborating the studies of Panachuki et al. (2011), who evaluated soil erosion losses in typical Aluminoferric Red Latosol.

Considering the above, it is observed that this low soil loss value possibly reflects the high quality of the soil of this experiment, and that soil loss may be occurring due to other factors, such as those associated with climate. 
Amado, Prochnow, and Eltz (2002) analyzed the influence of climatic anomalies such as El Niño and La Niña in the soil and water loss and verified that the losses were more pronounced in the years of occurrence of El Niño. The authors indicate that the frequent and intense rainfall during the phenomenon require special measures of erosion control, and the NTS presents an important alternative of coexistence with this climatic anomaly. Although in the present study there was influence of El Niño, soil loss rates were lower than those found in the literature, largely due to the management system used.

As for water loss, soil loss is more largely influenced by BD in conjunction with Ksat (Equation 2).

$$
\text { Soil Loss }=-0.395+0.326 \mathrm{BD}-0.00068 \mathrm{Ksat} \quad\left(\mathrm{R}^{2}=69.56 \%\right)
$$

As in water loss, soil loss behavior was presented as a function of BD, Macro, and Ksat. The Micro was not considered since it is related to the Macro.

In Figure 4, graphs (a), (b) and (c) show the correlations between the soil loss, BD, Macro and Ksat variables. Regarding the statistical adjustments, models (a) and (b) present a median coefficient of determination of $69.56 \%$ and $65.20 \%$.
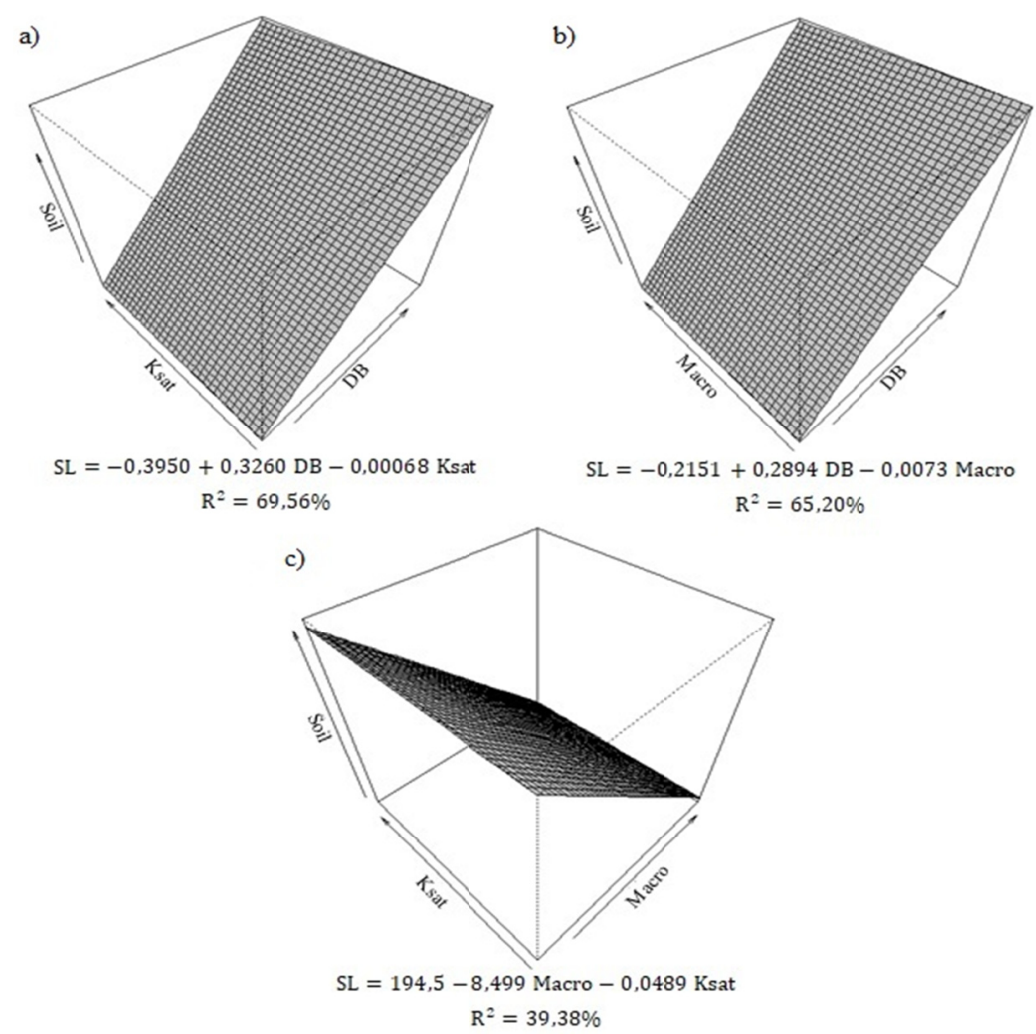

Figure 4. Graphs of the mathematical models for soil loss as a function of BD vs. Macro (a), BD vs. Ksat (b), and Macro vs. Ksat (c)

As shown in Figure 3, graphs (a), (b) and (c) show that water and soil loss may be related to BD, Macro, and Ksat. In both graphs (a) and (b) (Figure 4), it is observed that, irrespective of the value of Ksat and Macro, soil loss is more largely influenced by BD. As the values of BD increased, the greater the soil loss was due to runoff. These results corroborate with results found by Klein (2006), Santos, Griebeler, and Oliveira (2010), and Panachuk et al. (2011).

\subsection{Yield of Soybeans}

Table 4 presents soybean yield values in the gradients evaluated. It is verified that the mean soybean grain yield was higher in slope $13.4 \%$, although it did not differ from the slope of $8.2 \%$. 
Table 4. Soil grain yield values as a function of the slopes of the area

\begin{tabular}{ll}
\hline Slope $(\%)$ & Soybean grain yield $\left(\mathrm{Mg} \mathrm{ha}^{-1}\right)$ \\
\hline 3.5 & $1.64 \mathrm{~b}$ \\
8.2 & $1.98 \mathrm{ab}$ \\
11.4 & $1.54 \mathrm{~b}$ \\
13.4 & $2.22 \mathrm{a}$ \\
\hline
\end{tabular}

Note. Treatments means followed by distinct letters in the column differ statistically by Tukey's test at $5 \%$ significance.

The results are like those obtained by Alberto et al. (2006), who, in years in which the climatic phenomenon called El Niño, found soybean yield values varying from $4.86 \mathrm{Mg} \mathrm{ha}^{-1}$ to $1.1 \mathrm{Mg} \mathrm{ha}^{-1}$, as a reflection of the variability in rainfall distribution.

In Paraná, according to data from CONAB (2016), the mean soybean grain yield per hectare was $3.141 \mathrm{Mg} \mathrm{ha}^{-1}$ in the 2015-2016 harvest, these results being higher than those found in this study. In Paraná, the climate during the 2015-2016 harvest presented a variable behavior, maintaining atmospheric instability over the whole state, affecting soybean crops, in which many plants presented superficial roots because of the excessive rainfall and lack of luminosity (CONAB, 2016). Overall production for the 2015-2016 harvest, estimated at 95.4 million metric tons, was $0.8 \%$ below that of the 2014-2015 harvest.

To consider only the effect of the 5 variables under study, soil loss (Soil L), water loss (Water L), bulk density (BD), macroporosity (Macro) and saturated hydraulic conductivity (Ksat), yield data were corrected for an average number of plants per hectare, as some of the experimental units underwent caterpillar attacks.

In the regression analysis, by the stepwise method, the variables that best explain the soybean grain yield are water loss and soil loss (Equation 3).

$$
\text { Soybean grain yield }=2.8+4.8 \text { Soil } \mathrm{L}-6.4 \times 10^{-5} \text { Water } \mathrm{L} \quad\left(\mathrm{R}^{2}=69.90 \%\right)
$$

The highest slope of the soil presented higher soybean grains yield, and it should be noted that this effect may have occurred only at random. Considering that the soil loss was relatively low, according to the findings in the literature, and that the highest slope had a higher soybean grain yield, it should be noted that this effect may have occurred only at random.

In Figure 5, the soybean grain yield surface graph is presented as a function of water loss and soil loss.

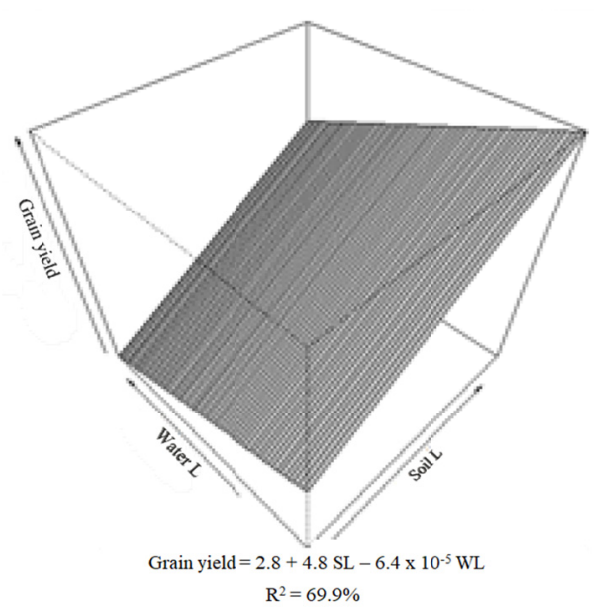

Figure 5. Soybean grain yield model graph as a function of soil loss (Soil L) and water loss (Water L)

In Figure 5, it is observed that, irrespective of the water loss value, the increase in soil loss results in a higher soybean grain yield of the crop. 
Such models can demonstrate that, as the crop did not suffer any drought during its cycle, having availability of water, other variables did not interfere in productivity. An explanation may be the fact that in the period 2015-2016, the soil had water available due to the high rainfall rates in the western region of the state of Paraná, in which, based on a series of studies, Den Biggelaar et al. (2001) determined that the yield decline in dry years is more significant than in years with abundant rainfall.

Several factors can affect crop yield because of the interaction of the effects of surface soil loss (Brunel et al., 2011). Oyedele and Aina (2006) concluded that the primary impacts of soil removal affect soil physical properties and organic matter content significantly more than other chemical properties.

\section{Conclusion}

The unevenness of the terrain did not influence soil and water loss rates.

The maximum soil and water losses during the soybean cycle were, respectively, $0.01962 \mathrm{Mg} \mathrm{ha}^{-1}$ and 4.07 $\mathrm{m}^{3} \mathrm{ha}^{-1}$

The maximum soil and water losses occurred when the precipitation volume was up to $82 \mathrm{~mm}$.

Soil and water loss showed a higher correlation with macroporosity and bulk density.

Soybean grain yield showed a higher linear correlation with water and soil loss and was higher in slopes of 8.2 and $13.4 \%$.

The low water and soil losses demonstrate the soil capacity, managed under a no-tillage system, to minimize environmental impacts

\section{References}

Alberto, C. M., Medeiros, S. L. P., Streck, N. A., Heldwein, A. B., Buriol, G. A., \& Medeiros, S. L. P. (2006). Água no solo e rendimento do trigo, soja e milho associados ao El Niño Oscilação Sul. Pesquisa Agropecuária Brasileira, 41, 1067-1075. https://doi.org/10.1590/S0100-204X2006000700001

Amado, T. J. C., Prochnow, D., \& Eltz, F. L. F. (2002). Perdas de solo e água em períodos de anomalias climáticas: "El Niño" e "La Niña" no sul do Brasil. Revista Brasileira de Ciência do Solo, 26(3), 819-827. https://doi.org/10.1590/S0100-06832002000300028

Amaral, A. J., Bertol, I., Cogo, N. P., \& Barbosa, F. T. (2008). Redução da erosão hídrica em três sistemas de manejo do solo em um Cambissolo Húmico da região do Planalto Sul-Catarinense. Revista Brasileira de Ciência do Solo, 32(5), 2145-2155. https://doi.org/10.1590/S0100-06832008000500035

Argenton, J., Albuquerque, J. A., Bayer, C., \& Wildner, L. P. (2005). Comportamento de atributos relacionados com a forma da estrutura de Latossolo Vermelho sob sistemas de preparo e plantas de cobertura. Revista Brasileira de Ciência do Solo, 29, 425-435. https://doi.org/10.1590/S0100-06832005000300013

Bertol, I. (1994). Erosão hídrica em Cambissolo húmico distrófico sob diferentes preparos do solo e rotação de culturas. Revista Brasileira de Ciência do Solo, 18, 267-271. Retrieved from http://www.scielo.br/ scielo.php?script $=$ sci_issues\&pid=0100-0683\&lng=en\&nrm=iso

Bertol, I., Beutler, J. F., Leite, D., \& Batistela, O. (2001). Propriedades físicas de um Cambissolo Húmico afetadas pelo tipo de manejo do solo. Scientia Agricola, 58, 555-560. https://doi.org/10.1590/S010390162001000300018

Bertol, I., Cogo, N. P., \& Levien, R. (1989). Cobertura morta e métodos de preparo do solo na erosão hídrica em solo com crosta. Revista Brasileira de Ciência do Solo, 13, 373-379. Retrieved from http://www.scielo.br/ scielo.php?script $=$ sci_issues\&pid=0100-0683\&lng=en\&nrm=iso

Bertol, I., González, A. P., \& Vázquez, E. V. (2007). Rugosidade superficial do solo sob diferentes doses de resíduo de milho submetido à chuva simulada. Pesquisa Agropecuária Brasileira, 42, 103-110. https://doi.org/10.1590/S0100-204X2007000100014

Beutler, A. N., \& Centurion, J. F. (2003). Efeito do conteúdo de água e da compactação do solo na produção de soja. Pesquisa Agropecuária Brasileira, 38(7), 849-856. https://doi.org/10.1590/S0100-204X200300070 0009

Brunel, N., Meza, F., Ros, R., \& Santibanez, F. (2011). Effects of topsoil loss on wheat productivity in dryland zones of Chile. Journal of Soil Science and Plant Nutrition, Temuco, 11(4), 129-137. https://doi.org/ $10.4067 / \mathrm{S} 0718-95162011000400010$ 
Cândido, B. M., Silva, M. L. N., Curi, N., \& Batista, P. V. G. (2014). Erosão hídrica pós-plantio em florestas de eucalipto na bacia do rio Paraná, no leste do Mato Grosso do Sul. Revista Brasileira de Ciência do Solo, 38, 1565-1575. https://doi.org/10.1590/S0100-06832014000500022

Carlesso, R., Spohr, R. B., Eltz, F. L. F., \& Flores, C. H. (2011). Runoff estimation in southern Brazil based on smith's modified model and the curve number method. Agricultural Water Management, 98(6), 1020-1026. https://doi.org/10.1016/j.agwat.2011.01.012

Carvalho, D. F., Souza, W. J., Pinto, M. F., Oliveira, J. R., \& Guerra, J. G. M. (2012). Perdas de água e solo sob diferentes padrões de chuva simulada e condições de cobertura do solo. Engenharia Agrícola, 32(4), 708-717. https://doi.org/10.1590/S0100-69162012000400010

Caviglione, J. H., Kiihl, L. R. B., Caramori, P. H., \& Oliveira, D. (2000). Cartas climáticas do Paraná. Londrina: IAPAR. Retrieved from http://www.iapar.br/pagina-677.html

Cogo, N. P., Levien, R., \& Schwarz, R. A. (2003). Perdas de solo e água por erosão hídrica influenciadas por métodos de preparo, classes de declive e níveis de fertilidade do solo. Revista Brasileira de Ciência do Solo, 27(4), 743-753. https://doi.org/10.1590/S0100-06832003000400019

CONAB (Companhia Nacional de Abastecimento). (2016). Acompanhamento da safra brasileira de grãos (v. 4, Safra 2015/16, pp. 1-154). Quarto Levantamento, Brasília. Retrieved from http://www.agricultura.gov.br/ noticias/produtor-brasileiro-esta-otimista-com-nova-safra-de-graos-diz-secretario-de-politica-agricola/2.pdf

Costa, T. T. C., Uzeda, M., Fidalgo E. C. C., Lumbreras, J. F., Zaroni, M., \& Guimarães, S. P. (2007). Vulnerabilidade ambiental em sub-bacias hidrográficas do Estado do Rio de Janeiro por meio de integração temática da perda de solo (USLE), variáveis morfométricas e o uso/cobertura da terra (pp. 2493-2500). Anais XIII Simpósio Brasileiro de Sensoriamento Remoto, Florianopólis, Brazil. Retrieved from https://www.alice.cnptia.embrapa.br/alice/bitstream/doc/1010640/1/Vulnerabilidadeambiental.pdf

Den Biggelaar, C., Lal, R., Wiebe, K., \& Breneman, V. (2001). Impact of soil erosion on crop yields in North America. Advances in Agronomy, 72, 1-52. https://doi.org/10.1016/S0065-2113(01)72010-X

EMBRAPA (Empresa Brasileira de Pesquisa Agropecuária). (2011). Manual de métodos de análise de solos. Centro Nacional de Pesquisa de Solos (2nd ed., p. 230). Rio de Janeiro: Embrapa Solos.

EMBRAPA (Empresa Brasileira de Pesquisa Agropecuária). (2013). Sistema brasileiro de classificação de solos. Centro Nacional de Pesquisa de Solos (3rd ed.). Brasília: Ministério da Agricultura e do Abastecimento.

Farias, J. R. B., Neumaier, N., \& Nepomuceno, A. L. (2015). Exigências climáticas. Empresa Brasileira de Pesquisa Agropecuaria-Seca: Soja em carência de água. Londrina: Embrapa Soja. Retrieved from http://bioinfo.cnpso.embrapa.br/seca/índex.php/clima

Fontana, A., Teixeira, W. G., Balieiro, F. C., Moura, T. P. A., Menezes, A. R., \& Santana, C. I. (2016). Características e atributos de Latossolos sob diferentes usos na região Oeste do Estado da Bahia. Pesquisa Agropecuária Brasileira, 51(9), 1457-1465. https://doi.org/10.1590/s0100-204x2016000900044

Hamza, M. A., \& Anderson, W. K. (2005). Soil compaction in cropping systems: A review of the nature, causes and possible solutions. Soil and Tillage Research, 82, 121-145. https://doi.org/10.1016/j.still.2004.08.009

IPARDES (Instituto Paranaense de Desenvolvimento Econômico e Social). (2012). Anuário Estatístico do Estado do Paraná, 2012. Retrieved from http://www.ipardes.gov.br/perfil_municipal/MontaPerfil.php? codlocal $=171 \& \mathrm{btOk}=\mathrm{ok}$

Klein, V. A. (2006). Densidade relativa-Um indicador da qualidade física de um Latossolo Vermelho. Revista Ciência Agronômica, 5, 26-32. Retrieved from www.scielo.br/scielo.php?script=sci_nlinks\&ref=000077 \&pid=S01038478200900090001400005\&lng=pt

Lanzanova, M. E., Eltz, F. L. F., Nicoloso, R. S., Cassol, E. A., Bertol, I., Amado, T. J. C., \& Girardello, V. C. (2013). Residual effect of soil tillage on water erosion from a Typic Paleudalf under long-term no-tillage and cropping systems. Revista Brasileira de Ciência do Solo, 37, 1689-1698. https://doi.org/10.1590/ S0100-06832013000600025

Leite, M. H. S., Couto, E. G., Amorim, R. S. S., Costa, E. L., \& Maraschin, L. (2009). Perdas de solo e nutrientes num Latossolo vermelho-amarelo ácrico típico, com diferentes sistemas de preparo e sob chuva natural. Revista Brasileira de Ciência do Solo, 33, 689-699. https://doi.org/10.1590/S0100-06832009000300021 
Levien, R., Cogo, N. P., \& Rockenbach, C. A. (1990). Erosão na cultura do milho em diferentes sistemas de cultivo anterior e métodos de preparo do solo. Revista Brasileira de Ciência do Solo, 14, 73-80. Retrieved from http://www.scielo.br/scielo.php?script=sci_issues\&pid=0100-0683\&lng=en\&nrm=iso

Marques, S. R., Weill, M. A. M., \& Silva, L. F. S. (2010). Qualidade física de um latossolo vermelho, perdas por erosão e desenvolvimento do milho em dois sistemas de manejo. Ciência e Agrotecnologia, 34(4), 967-974. https://doi.org/10.1590/S1413-70542010000400024

Martins Filho, M. V., Pereira, V. P., \& Marques Júnior, J. (2001). Efeitos da densidade do solo na erosão de um Latossolo Vermelho devido ao tráfego. Engenharia Agrícola, 21, 23-31. Retrieved from http://www.engenhariaagricola.org.br

Mesquita, M. G. B. F., \& Moraes, S. O. (2004). A dependência entre a condutividade hidráulica saturada e atributos físicos do solo. Ciência Rural, 34(3), 963-969. https://doi.org/10.1590/S0103-847820040003 00052

Michellon, E., Reydon, B. P., \& Chicati, M. L. (2014). Impacto econômico do manejo de solo e água em microbacias hidrográficas paranaenses. Revista Agropecuária Técnica, 35(1), 54-61. Retrieved from http://www.periodicos.ufpb.br/index.php/at/article/download/10243/10744

Minella, J. P. G., Merten, G. H., Reichert, J. M., \& Santos, D. R. (2007). Identificação e implicações para a conservação do solo das fontes de sedimentos em bacias hidrográficas. Revista Brasileira de Ciência do Solo, 31, 1637-1646. https://doi.org/10.1590/S0100-06832007000600039

Moline, E. F. V., Farias, E. A. P., Brasilino, M. F., Barboza, E., \& Schlindwein, J. A. (2011). Redução das Perdas de Água e Solo em Função do Volume de Palhada na Superfície de um Solo em Rondônia. Global Science and Technology, 4(2), 91-97. Retrieved from https://rv.ifgoiano.edu.br/periodicos/index.php/gst/article/ view/413/261

Oliveira, J. R., Pinto, M. F., Souza, W. J., Guerra, J. G. M., \& Carvalho, D. F. (2010). Erosão hídrica em um argissolo vermelho-amarelo, sob diferentes padrões de chuva simulada. Revista Brasileira de Engenharia Agricola e Ambiental, 14(2), 140-147. https://doi.org/10.1590/S1415-43662010000200004

Oyedele, D. J., \& Aina, P. O. (2006). Response of soil properties and maize yield to simulated erosion by artificial topsoil removal. Plant and Soil, 284, 375-384. https://doi.org/10.1007/s11104-006-0041-0

Panachuki, E., Bertol, I., Alves Sobrinho, T., Oliveira, P. T. S., \& Rodrigues, D. B. B. (2011). Soil and water loss and water infiltration in red latosol under different management systems. Revista Brasileira de Ciência do Solo, 35(5), 1777-1786. https://doi.org/10.1590/S0100-06832011000500032

Primo, J. T. A., Silva, T. G. F., Silva, S. M. S., Moura, M. S. B., \& Souza, L. S. B. (2015). Calibração de sondas capacitivas, funções físico-hídricas e variação do armazenamento de água em um argissolo cultivado com palma forrageira. Revista Ceres, 62(1), 20-29. https://doi.org/10.1590/0034-737X201562010003

$\mathrm{R}$ Core Team. (2016). R: A language and environment for statistical computing. R Foundation for Statistical Computing, Vienna, Austria. Retrieved from https://www.R-project.org

Ramos, M. R., Favaretto, N., Uhlmann, A., Dieckow, J., Vezzani, F. M., \& Almeida, L. (2015). Produção de hortaliças no sistema orgânico: Efeito nos atributos físicos do solo. Revista de Ciências Agrárias, 58, 45-51. https://doi.org/10.4322/rca.1666

Reichert, J. M., Reinert, D. J., \& Braida, J. A. (2003). Qualidade dos solos e sustentabilidade de sistemas agrícolas. Ciência Ambiental, 27, 29-48. Retrieved from http://www.academia.edu/19725658/Qualidade_ dos_solos_e_sustentabilidade_de_sistemas_agrícolas

Reichert, J. M., Suzuki, L. E. A. S., Reinert, D. J., Horn, R., \& Hakansson, I. (2009). Reference bulk density and critical degree-of-compactness for no-till crop production in subtropical highly weathered soils. Soil and Tillage Research, 102, 242-254. https://doi.org/10.1016/j.still.2008.07.002

Santos, G. G., Griebeler, N. P., \& Oliveira, L. F. C. (2010). Chuvas intensas relacionadas à erosão hídrica. Revista Brasileira de Engenharia Agrícola e Ambiental, 14(2), 115-123. https://doi.org/10.1590/S141543662010000200001

Santos, H. L., Marques Júnior, J., Matias, S. S. R., Siqueira, D. S., \& Martins Filho, M. V. (2013). Erosion factors and magnetic susceptibility in differet compartments of a slope in Gilbués-PI, Brazil. Engenharia Agricola, 33(1), 64-74. https://doi.org/10.1590/S0100-69162013000100008 
Schick, J., Bertol, I., Batistela, O., \& Balbino Júnior, A. A. (2000). Erosão hidrica em Cambissolo Húmico Alumínico submetido a diferentes sistemas de preparo e cultivo do solo: I. Perdas de solo e água. Revista Brasileira de Ciência do Solo, 24, 427-436. https://doi.org/10.1590/S0100-06832000000200019

Silva, A. M., Silva, M. L. N., Curi, N., Avanzi, J. C., \& Ferreira, M. M. (2009). Erosividade da chuva e erodibilidade de Cambissolo e Latossolo na região de Lavras, sul de Minas Gerais. Revista Brasileira de Ciência do Solo, 33(6), 1811-1820. https://doi.org/10.1590/S0100-06832009000600029

Silva, R. L., \& De Maria, I. C. (2011). Erosão em sistema plantio direto: influência do comprimento de rampa e da direção de semeadura. Revista Brasileira de Engenharia Agrícola e Ambiental, 15(6), 554-561. https://doi.org/10.1590/S1415-43662011000600003

Sousa, G. B., Martins Filho, M. V., \& Matias, S. S. R. (2012). Perdas de solo, matéria orgânica e nutrientes por erosão hídrica em uma vertente coberta com diferentes quantidades de palha de cana-de-açúcar em Guariba-SP. Engenharia Agrícola, 32(3), 490-500. https://doi.org/10.1590/S0100-69162012000300008

Tiecher, T., Minella, J. P. G., Miguel, P., Alvarez, J. W. R., Pellegrini, A., Capoane, V., ... Santos, D. R. D. (2014). Contribuição das fontes de sedimentos em uma bacia hidrográfica agrícola sob plantio direto. Revista Brasileira de Ciência do Solo, 38, 639-649. https://doi.org/10.1590/S0100-06832014000200028

Tormena, C. A., Barbosa, M. C., Costa, A. C. S., \& Gonçalves, A. C. A. (2002). Densidade, porosidade e resistência à penetração em Latossolo cultivado sob diferentes sistemas de preparo do solo. Scientia Agricola, 59(4), 795-801. https://doi.org/10.1590/S0103-90162002000400026

Vanni, S. M. (1998). Modelos de regressão: Estatística aplicada (p. 177). São Paulo: Legmar Informática \& Editora.

\section{Copyrights}

Copyright for this article is retained by the author (s), with first publication rights granted to the journal.

This is an open-access article distributed under the terms and conditions of the Creative Commons Attribution license (http://creativecommons.org/licenses/by/4.0/). 